\title{
Evaluation of Liquefaction Potential of a Coastal Region in Atakum
}

\author{
M. Kerem Ertek¹, Gökhan Demir ${ }^{1}$, Kemal Hacıefendioğlu' ${ }^{1}$, S. Banu İkizler² \\ ${ }^{1}$ Ondokuz Mayis University \\ Samsun, Turkey \\ mkerem.ertek@omu.edu.tr; gokhan.demir@omu.edu.tr; hckemal@omu.edu.tr \\ ${ }^{2}$ Karadeniz Technical University \\ Trabzon, Turkey \\ banuh@ktu.edu.tr
}

\begin{abstract}
Liquefaction became a major seismic phenomena just after the earthquakes occurred in Alaska and Niigata in 1964. Soil liquefaction is one of the most important causes of damages induced by earthquakes. Liquefaction can be defined as temporary loss of strength of saturated, coheisonless soil deposits under transient and cyclic loading due to excess pore water pressure generation. Consequently, the most appropriate and typical soil condition which brings the potential out to liquefy is loose sand with a groundwater table close to ground surface. This study is concerned with determination of liquefaction potential in a coastal region in Atakum County of Samsun Province, Turkey. Therefore, empirical equations were used to determine the peak ground accelerations for three scenario earthquakes with the magnitudes of 6.5, 7.0 and 7.2 in order to consider in the Simplified Procedure context proposed by Seed and Idriss (1971). Liquefaction potential evaluations were performed using SPT blow counts for four boreholes for sandy portions of the soil profile which exist in the first 20 meters below ground surface. In addition to analytical evaluations, two dimensional nonlinear analyses were ran with Towhata-Iai constitutive model suitable for liquefaction analysis available in DIANA finite element software to clarify excess pore pressure generation that leads to liquefaction. Finally, all the results are presented and discussed as a conclusion.
\end{abstract}

Keywords: Liquefaction, SPT, Pore pressure, Towhata-Iai

\section{Introduction}

Liquefaction became a major seismic phenomena just after the earthquakes occurred in Alaska and Niigata in 1964 [1]. The North Anatolian Fault Zone (NAFZ) caused a devastating earthquake $\left(M_{w}=7.2\right)$ in Ladik in 1942 which extends along south of study area in Atakum with a distance of $55 \mathrm{~km}$ approximately. Hence, it becomes an important issue to evaluate liquefaction potential for coastal regions of Atakum County since it has soils with alluvial origin and has high groundwater level.

This study aims to evaluate the liquefaction potential and liquefaction induced settlements in study area (Fig.1) for three scenario earthquakes with the magnitudes of 6.5, 7.0 and 7.2. The most common in-situ test and method used for assessment of liquefaction potential is Standard Penetration Test (SPT) and Simplified Procedure proposed by Seed and Idriss (1971) respectively.

Standard Penetration Tests were performed through four boreholes at depths that are multiples of $1.5 \mathrm{~m}$ down from the surface. Soil sections in these boreholes and corrected SPT-N values can be seen in Fig. 2 and the geotechnical properties of the soils obtained by laboratory tests are given in Table 1. As can be seen in Fig. 2, the soil profile forms of surface soil uppermost. The thickness of this surface soil alters from $0.8 \mathrm{~m}$ to $2.2 \mathrm{~m}$ above the sand and silty sand portions located in between the overburden and $16.5 \mathrm{~m}$ approximately. According to the case studies, the soil susceptible to liquefaction usually extends from the ground surface to a depth of $15 \mathrm{~m}$. It's because deeper soils have higher confining pressures, generally preventing liquefaction. However, it is common to evaluate liquefaction potential to a depth of $20 \mathrm{~m}$. In the study area, clay strata takes place between the depths of $16.5 \mathrm{~m}$ to levels deeper than $20 \mathrm{~m}$ which ensures it is sufficient to determine liquefaction potential for the top $16.5 \mathrm{~m}$. 

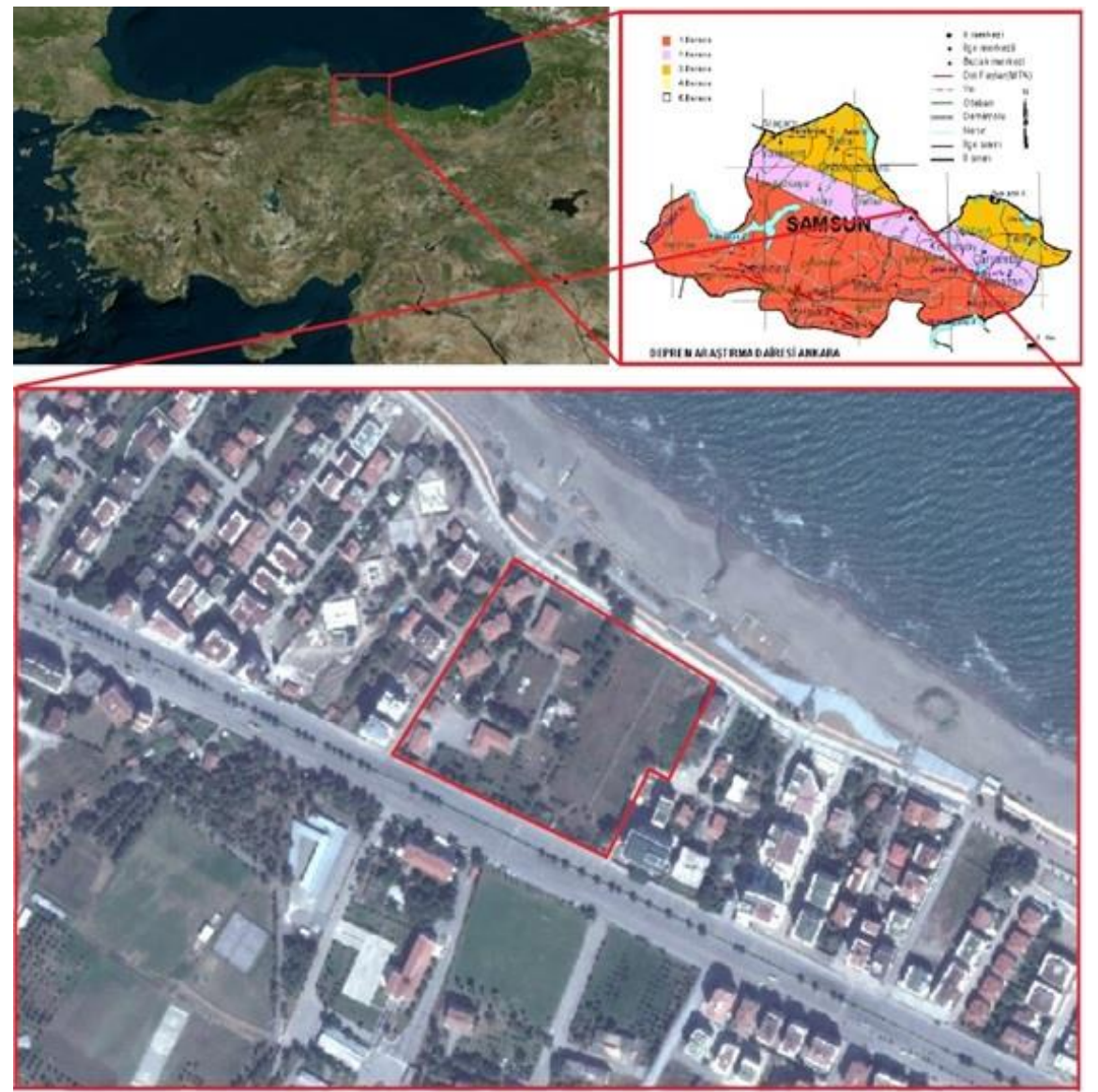

Fig. 1: Study area.

Table 1: General properties for soil.

\begin{tabular}{|c|c|c|c|c|c|c|c|c|c|c|}
\hline \multirow[b]{2}{*}{ Borehole } & \multirow[b]{2}{*}{$\begin{array}{l}\text { Sample } \\
\text { Type }\end{array}$} & \multirow[b]{2}{*}{$\begin{array}{l}\text { Depth } \\
\text { (m) }\end{array}$} & \multirow{2}{*}{$\begin{array}{c}\text { Water } \\
\text { Content } \\
\mathrm{W}_{\mathrm{n}}, \\
(\%)\end{array}$} & \multirow{2}{*}{$\begin{array}{c}\text { Mass } \\
\text { Density } \\
\left(\gamma_{\mathrm{n}}\right) \\
\left(\mathrm{kN} / \mathrm{m}^{3}\right)\end{array}$} & \multicolumn{2}{|c|}{ Sieve Analysis } & \multicolumn{3}{|c|}{ Atterberg Limits } & \multirow[b]{2}{*}{$\begin{array}{c}\text { Soil Types } \\
\text { (USCS) }\end{array}$} \\
\hline & & & & & $\begin{array}{c}\text { Sand } \\
(\%)\end{array}$ & $\begin{array}{c}\text { Silt-Clay } \\
\text { (- ) } 200 \\
(\%)\end{array}$ & $\begin{array}{l}\text { LL } \\
(\%)\end{array}$ & $\begin{array}{l}\text { PL } \\
(\%)\end{array}$ & $\begin{array}{c}\text { PI } \\
(\%)\end{array}$ & \\
\hline \multirow{5}{*}{ BH-1 } & SPT & $4.50-4.95$ & 10.6 & - & 97 & 3 & \multicolumn{3}{|c|}{ Non-plastic } & SW \\
\hline & SPT & $10.50-10.95$ & 17.9 & - & 95 & 5 & \multicolumn{3}{|c|}{ Non-plastic } & SW-SM \\
\hline & UD & $18.00-18.50$ & 27.9 & 19.4 & 11 & 89 & 33 & 21 & 12 & $\mathrm{CL}$ \\
\hline & SPT & $22.50-22.95$ & 25.4 & 19.7 & 79 & 21 & \multicolumn{3}{|c|}{ Non-plastic } & SM \\
\hline & Core Drill & $28.00-28.10$ & 24.0 & 18.1 & & & \multicolumn{3}{|c|}{ Non-plastic } & \\
\hline \multirow{2}{*}{ BH-2 } & SPT & $6.00-6.45$ & 22.0 & - & 94 & 6 & \multicolumn{3}{|c|}{ Non-plastic } & SW-SM \\
\hline & SPT & $9.00-9.45$ & 20.4 & - & 92 & 8 & \multicolumn{3}{|c|}{ Non-plastic } & SW-SM \\
\hline \multirow{5}{*}{ BH-3 } & SPT & $3.00-3.45$ & 24.4 & - & 79 & 21 & \multicolumn{3}{|c|}{ Non-plastic } & SM \\
\hline & SPT & $15.00-15.45$ & 22.3 & - & 73 & 27 & \multicolumn{3}{|c|}{ Non-plastic } & SM \\
\hline & SPT & $17.50-17.95$ & 27.0 & - & 10 & 90 & \multicolumn{3}{|c|}{ Non-plastic } & ML \\
\hline & SPT & $21.00-21.45$ & 20.2 & - & 82 & 18 & \multicolumn{3}{|c|}{ Non-plastic } & SM \\
\hline & Core Drill & $29.00-29.20$ & 20.1 & 19.7 & & & \multicolumn{3}{|c|}{ Non-plastic } & \\
\hline
\end{tabular}




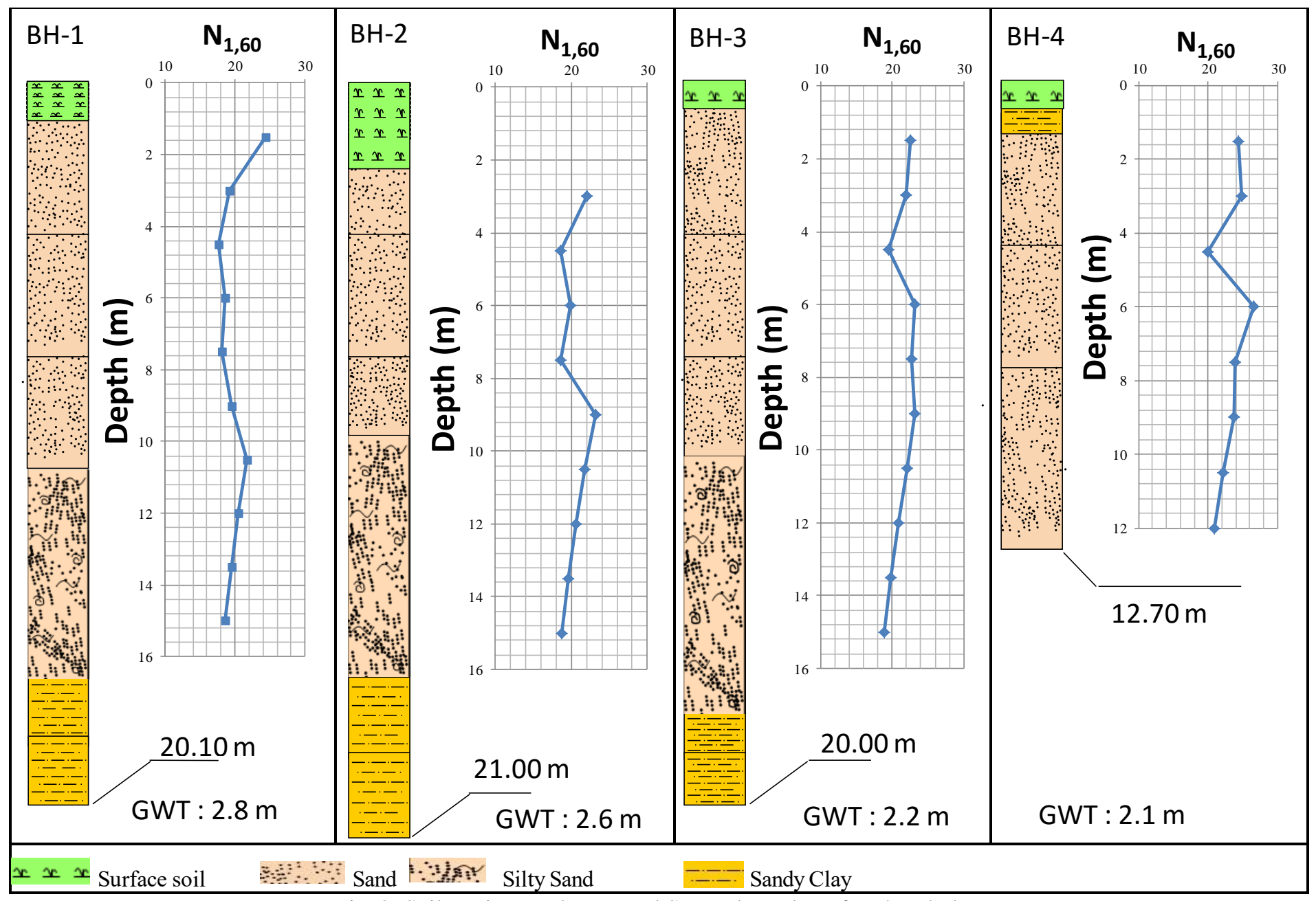

Fig. 2: Soil sections and corrected SPT values along four boreholes.

\section{Determination of Liquefaction Potential}

The most common type of analysis to determine the liquefaction potential is to use the SPT $[3,4]$. The analysis is based on the simplified method proposed by Seed and Idriss (1971) which is commonly known as the Simplified Procedure.

\subsection{Cyclic Stress Ratio}

In Simplified procedure, Cyclic Stress Ratio (CSR) has to be found using equation below[2,4]:

$$
\operatorname{CSR}=0.65 r_{d}\left(\frac{\sigma_{\mathrm{vo}}}{\sigma_{\mathrm{vo}}^{\prime}}\right)\left(\frac{\mathrm{a}_{\mathrm{max}}}{\mathrm{g}}\right)
$$

In Eq. (1), $a_{\max }$ is the peak ground acceleration, $r_{d}$ is depth reduction factor and both can be respectively determined with the following equations:

$$
\begin{gathered}
\mathrm{a}_{\max }=2.8\left(\mathrm{e}^{\left.0.9 \mathrm{M}_{\mathrm{w}} * \mathrm{e}^{-0.025 R}-1\right)}\right. \\
\mathrm{r}_{\mathrm{d}}=\frac{\left(1.000-0.4113 \mathrm{z}^{0.5}+0.04052 \mathrm{z}+0.001753 \mathrm{z}^{1.5}\right)}{\left(1.000-0.4177 \mathrm{z}^{0.5}+0.05729 \mathrm{z}-0.006205 \mathrm{z}^{1.5}+0.001210 \mathrm{z}^{2}\right)}
\end{gathered}
$$


In Eq. (2), $M_{w}$ is the magnitude of scenario earthquake and $R$ is the distance to fault [5]. In Eq. (3), $z$ is the depth beneath ground surface in meters [6].

\subsection{Cyclic Resistance Ratio}

The other essential component of Simplified Procedure is the Cyclic Resistance Ratio (CRR) which is calculated from the equation below:

$$
\mathrm{CRR}_{7.5}=\frac{1}{34-\left(\mathrm{N}_{1}\right)_{60}}+\frac{\mathrm{N}_{1,60}}{135}+\frac{50}{\left[10 \cdot \mathrm{N}_{1,60}+45\right]^{2}}-\frac{1}{200}
$$

In Eq. (4), $\mathrm{N}_{1,60}$ is the SPT blow count normalized to an overburden pressure of approximately $100 \mathrm{kPa}$ and a hammer energy ratio of $60 \%$ [6]. The following equation can be used to calculate $\mathrm{N}_{1,60}$ :

$$
\mathrm{N}_{1,60}=0.75\left(\mathrm{C}_{\mathrm{N}}\right)\left(\mathrm{C}_{\mathrm{R}}\right) \mathrm{N}_{\mathrm{m}}
$$

In Eq. (5), $C_{R}$ is the correction factor for rod length which can be taken from Table 2 [4] and $C_{N}$ is the overburden stress correction factor [6] that might be smaller than 1.60 [7], can be calculated by the equation below [8]:

$$
\mathrm{C}_{\mathrm{N}}=\left(\mathrm{P}_{\mathrm{a}} / \sigma_{\mathrm{v} 0}^{\prime}\right)^{0.5}
$$

$\mathrm{C}_{\mathrm{N}}$ is used to normalize SPT blow count to an effective overburden pressure $\sigma_{\mathrm{v} 0}^{\prime}$ of approximately $100 \mathrm{kPa} \mathrm{P}_{\mathrm{a}}[6]$.

Table 2: Rod length correction factors

\begin{tabular}{|c|c|}
\hline Rod Length & $\mathbf{C}_{\boldsymbol{R}}$ \\
\hline$<3 \mathrm{~m}$ & 0.75 \\
\hline $3-4 \mathrm{~m}$ & 0.8 \\
\hline $4-6 \mathrm{~m}$ & 0.85 \\
\hline $6-10 \mathrm{~m}$ & 0.95 \\
\hline $10-30 \mathrm{~m}$ & 1.0 \\
\hline
\end{tabular}

\subsection{Factor of Safety Against Liquefaction}

The final step in Simplified Procedure is to determine the factor of safety (FS) against liquefaction:

$$
\mathrm{FS}=\frac{\mathrm{CRR}_{7.5}}{\mathrm{CSR}} \mathrm{MSF}
$$

In Eq. (7), MSF is the magnitude scaling factor and has to be applied when the earthquake magnitude is not 7.5, cause the CRR calculated from Eq. (4) is for the earthquakes with a magnitude of 7.5. Magnitude scaling factors and peak ground accelerations calculated for three scenario earthquakes can be seen in Table 3.

The higher the factor of safety, the more resistant the soil is to liquefaction. However, soil that has a factor of safety slightly greater than 1.0 may stil liquefy during an earthquake. For example, if a layer liquefies, then the upward flow of water could induce liquefaction of the layer that has a factor of safety slightly greater than 1.0 [4]. Hence, in most cases, for the values of factor of safety between 1 and 1.2, it's considered that there still is a risk of liquefaction [9].

The values of factor of safety against liquefaction for four boreholes in the study area which has clean sand and silty sand layers for about $15 \mathrm{~m}$ was determined for three different scenario earthquakes and given in Fig. 3 and Table 4. 
Table 3: Magnitude scaling factors and peak accelerations.

\begin{tabular}{|c|c|c|}
\hline Magnitude $\left(\mathrm{M}_{\mathrm{w}}\right)$ & $\mathrm{a}_{\max }$ & $\mathrm{MSF}$ \\
\hline 6.5 & 0.248 & 1.442 \\
\hline 7.0 & 0.39 & 1.192 \\
\hline 7.2 & 0.468 & 1.109 \\
\hline
\end{tabular}

Table 4: Factor of safety against liquefaction.

\begin{tabular}{|c|c|c|c|c|c|c|}
\hline \multirow{2}{*}{ Borehole } & \multirow{2}{*}{$\begin{array}{c}\text { Depth } \\
(\mathrm{m})\end{array}$} & \multirow{2}{*}{$\begin{array}{c}\text { GWT } \\
(\mathrm{m})\end{array}$} & \multirow{2}{*}{$\mathrm{N}_{1,60}$} & $M_{W}=6.5$ & $\mathrm{M}_{\mathrm{W}}=7.0$ & $\mathrm{M}_{\mathrm{W}}=7.2$ \\
\hline & & & & FS & FS & $\mathrm{FS}$ \\
\hline \multirow{10}{*}{ BH-1 } & 1.5 & \multirow{10}{*}{2.8} & 24.30 & 2.79 & 1.47 & 1.03 \\
\hline & 3 & & 19.27 & 1.82 & 0.96 & 0.74 \\
\hline & 4.5 & & 17.62 & 1.38 & 0.73 & 0.56 \\
\hline & 6 & & 18.57 & 1.33 & 0.7 & 0.54 \\
\hline & 7.5 & & 18.15 & 1.23 & 0.65 & 0.50 \\
\hline & 9 & & 19.55 & 1.31 & 0.69 & 0.53 \\
\hline & 10.5 & & 21.69 & 1.48 & 0.78 & 0.60 \\
\hline & 12 & & 20.51 & 1.40 & 0.74 & 0.57 \\
\hline & 13.5 & & 19.50 & 1.37 & 0.72 & 0.56 \\
\hline & 15 & & 18.62 & 1.37 & 0.72 & 0.56 \\
\hline \multirow{10}{*}{ BH-2 } & 1.5 & \multirow{10}{*}{2.6} & - & - & - & - \\
\hline & 3 & & 22.11 & 2.06 & 1.08 & 0.84 \\
\hline & 4.5 & & 18.62 & 1.42 & 0.75 & 0.58 \\
\hline & 6 & & 19.94 & 1.41 & 0.74 & 0.57 \\
\hline & 7.5 & & 18.66 & 1.25 & 0.66 & 0.51 \\
\hline & 9 & & 23.27 & 1.60 & 0.84 & 0.65 \\
\hline & 10.5 & & 21.82 & 1.47 & 0.77 & 0.60 \\
\hline & 12 & & 20.62 & 1.39 & 0.73 & 0.57 \\
\hline & 13.5 & & 19.59 & 1.36 & 0.72 & 0.56 \\
\hline & 15 & & 18.71 & 1.36 & 0.71 & 0.55 \\
\hline \multirow{10}{*}{ BH-3 } & 1.5 & \multirow{10}{*}{2.2} & 22.50 & 6.34 & 1.34 & 0.92 \\
\hline & 3 & & 21.95 & 1.88 & 0.99 & 0.77 \\
\hline & 4.5 & & 19.48 & 1.41 & 0.74 & 0.57 \\
\hline & 6 & & 23.18 & 1.62 & 0.85 & 0.66 \\
\hline & 7.5 & & 22.69 & 1.52 & 0.80 & 0.62 \\
\hline & 9 & & 23.23 & 1.54 & 0.81 & 0.63 \\
\hline & 10.5 & & 22.09 & 1.45 & 0.76 & 0.59 \\
\hline & 12 & & 20.85 & 1.38 & 0.72 & 0.56 \\
\hline & 13.5 & & 19.79 & 1.35 & 0.71 & 0.55 \\
\hline & 15 & & 18.88 & 1.34 & 0.71 & 0.55 \\
\hline \multirow{8}{*}{ BH-4 } & 1.5 & \multirow{8}{*}{2.1} & 24.30 & 2.79 & 1.47 & 1.03 \\
\hline & 3 & & 24.78 & 2.20 & 1.16 & 0.90 \\
\hline & 4.5 & & 20.00 & 1.43 & 0.75 & 0.58 \\
\hline & 6 & & 26.57 & 2.02 & 1.06 & 0.82 \\
\hline & 7.5 & & 23.91 & 1.62 & 0.85 & 0.66 \\
\hline & 9 & & 23.68 & 1.57 & 0.83 & 0.64 \\
\hline & 10.5 & & 22.16 & 1.44 & 0.76 & 0.59 \\
\hline & 12 & & 20.90 & 1.37 & 0.72 & 0.56 \\
\hline
\end{tabular}




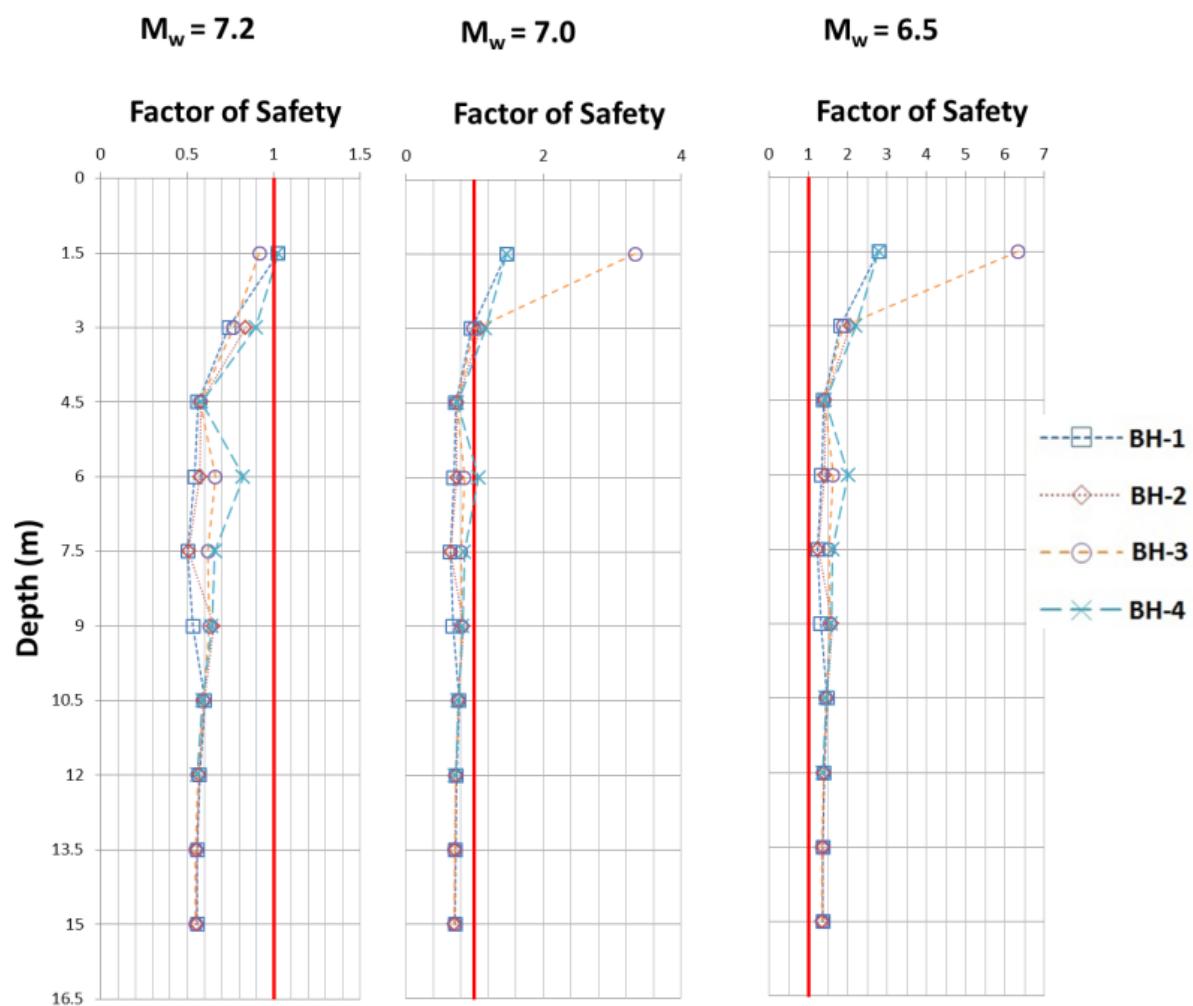

Fig. 3: Graphical presentation for factor of safety against liquefaction.

\section{Excess Pore Pressure Ratios}

Theoretically, liquefaction occurs when the effective stress of soil is reduced to essentially zero, which leads to a complete loss of shear strength or in other words, the increase in pore water pressures causes the effective stress to become equal to zero. So, the soil behaves as a liquid. But, according to the studies aimed to compare in situ and laboratory pore pressure responses, it's understood that a value greater than 0.9 is enough for excess pore pressure ratio to generate liquefaction $[10,11]$.

In this study, DIANA finite element software was used for the numerical analysis of excess pore pressure generation in which Towhata-Iai constitutive model is suitable for such kind of analysis. Finite element model and material properties for the soil layers can be seen in Fig. 4 and Table 5 respectively.

Time history of 1999 Düzce Earthquake with peak acceleration value of $0.513 \mathrm{~g}$ (WE component) was applied to the model (with the dimensions $18 \mathrm{~m} * 16.5 \mathrm{~m}$ ) after scaling the peak values of accelerations to fit those in Table 3 .

Excess pore pressure ratio values obtained from the numerical analyses can be seen in Table 6 and Fig. 5. These values generate after approximately 11 seconds (rise steadily until 11 seconds) and hold at the rest of the motion.

Table 5: Material properties for soil layers.

\begin{tabular}{|c|c|c|c|c|c|c|c|c|c|c|}
\hline Layer & $\begin{array}{c}\text { Depth } \\
(\mathrm{m})\end{array}$ & $\begin{array}{c}\sigma_{\mathrm{v} 0}^{\prime} \\
(\mathrm{kPa})\end{array}$ & $\mathrm{G}_{\mathrm{ref}}(\mathrm{kPa})$ & $\mathrm{K}_{\mathrm{ref}}(\mathrm{kPa})$ & $\mathrm{E}(\mathrm{kPa})$ & $\mathrm{S}_{1}$ & $\mathrm{~W}_{1}$ & $\mathrm{P}_{1}$ & $\mathrm{P}_{2}$ & $\mathrm{C}_{1}$ \\
\hline ZEM1 & 1 & 17.6 & - & - & 91703 & - & - & - & - & - \\
\hline ZEM2 & 2.5 & 44 & 51417 & 111403 & 144996 & 0.005 & 4 & 0.78 & 1 & 1.8 \\
\hline ZEM3 & 6.75 & 82.7 & 70490 & 152730 & 198784 & 0.005 & 7 & 0.78 & 1 & 1.5 \\
\hline ZEM4 & 13.5 & 150.2 & 94998 & 205829 & 267895 & 0.005 & 10 & 0.78 & 1 & 1.5 \\
\hline
\end{tabular}


Table 6: Excess pore pressure ratios.

\begin{tabular}{|c|c|c|c|}
\hline & \multicolumn{3}{|c|}{ Excess pore pressure ratio $\left(\mathrm{r}_{\mathrm{u}}\right)$} \\
\hline Depth $(\mathrm{m})$ & $\mathrm{a}_{\max }=0.25 \mathrm{~g}$ & $\mathrm{a}_{\max }=0.39 \mathrm{~g}$ & $\mathrm{a}_{\max }=0.468 \mathrm{~g}$ \\
\hline $2-3$ & 0.957 & 0.978 & 0.968 \\
\hline $3-4.5$ & 0.895 & 0.958 & 0.965 \\
\hline $4.5-6$ & 0.87 & 0.964 & 0.967 \\
\hline $6-7.5$ & 0.793 & 0.962 & 0.966 \\
\hline $7.5-9$ & 0.705 & 0.957 & 0.96 \\
\hline $9-10.5$ & 0.544 & 0.951 & 0.964 \\
\hline $10.5-12$ & 0.727 & 0.82 & 0.889 \\
\hline $12-13.5$ & 0.675 & 0.91 & 0.92 \\
\hline $13.5-15$ & 0.283 & 0.862 & 0.925 \\
\hline $15-16.5$ & 0.105 & 0.311 & 0.892 \\
\hline
\end{tabular}

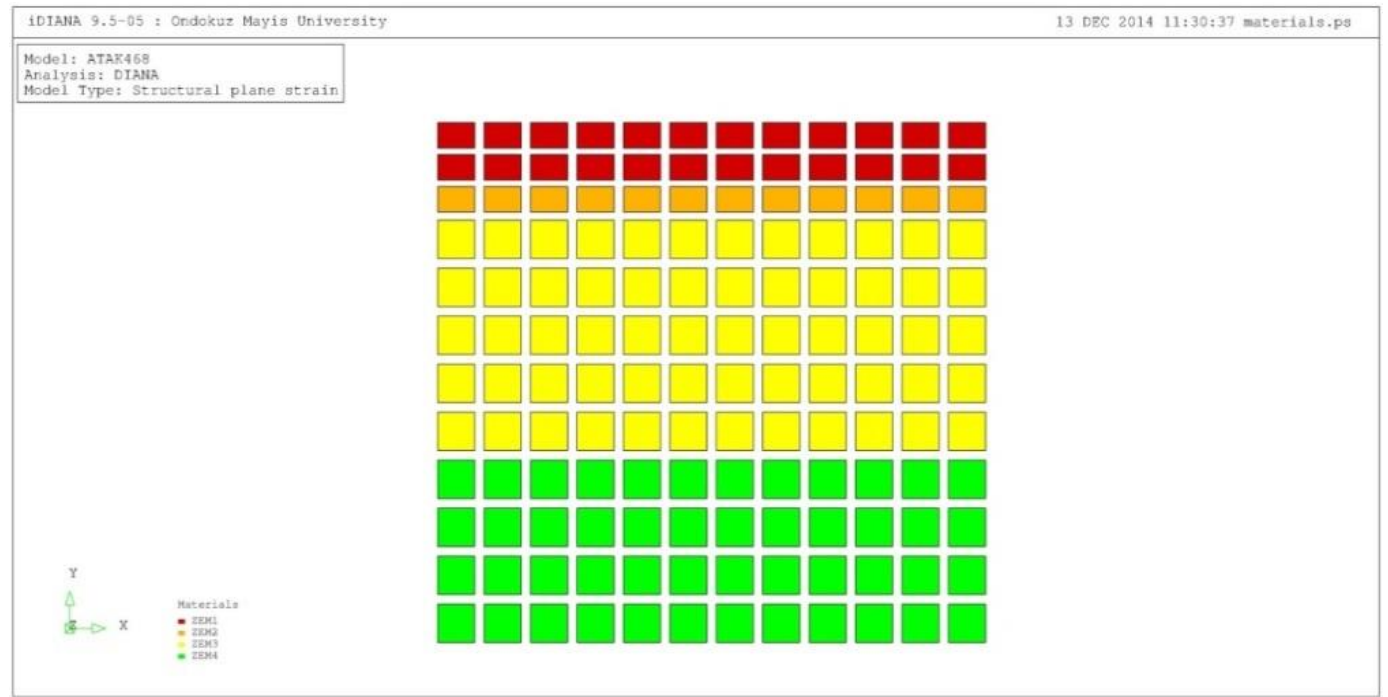

Fig. 4: Finite element model.

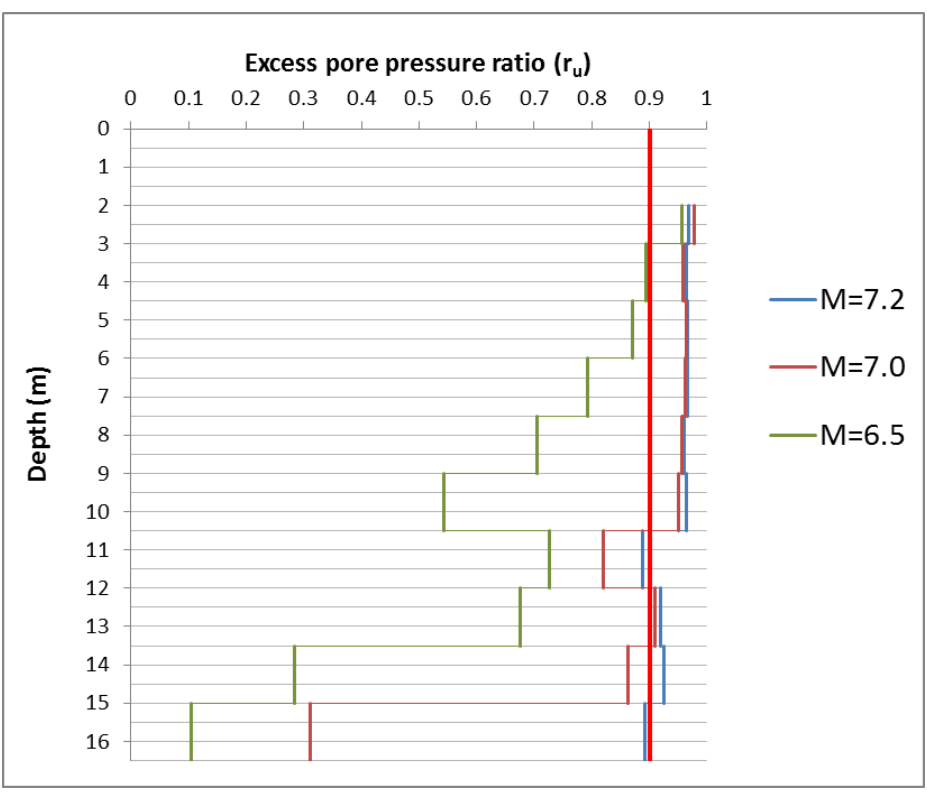

Fig. 5: Graphical presentation of excess pore pressures. 


\section{Conclusion}

Results obtained from the analyses with simplified procedure as well as numerical analyses with DIANA finite element software using Towhata-Iai constitutive model indicate that liquefaction phenomena importantly needs to be considered for the study area especially for the probable earthquakes with the magnitudes bigger than 7.0. This must be kept in mind for future structuring and also for existing superstructures and infrastructures in the area based upon the reality that liquefaction induced settlements, tilting and rupture of structures are one of the most hazardous manifestations of earthquakes.

\section{References}

[1] S. L. Kramer, Geotechnical earthquake engineering, Upper Saddle River, NJ: Prentice Hall, 1996.

[2] H. B. Seed and I. M Idriss, "Simplified Procedure for Evaluating Soil Liquefaction Potential," Journal of the Soil Mechanics and Foundation Div. (ASCE), vol. 97, no. 9, pp. 1249-1273, 1971.

[3] H. B. Seed, K. Tokimatsu, L. F. Harder, and R. Chung, "Influence Of Spt Procedures In Soil Liquefaction Resistance Evaluations," Journal of Geotechnical Engineering (ASCE), vol. 111, no. 12, pp. 1425-1445, 1985.

[4] R.W. Day, Geotechnical Earthquake Engineering Handbook, McGraw-Hill, 2002.

[5] O. Aydan, M. Sezaki, and R. Yarar, "The seismic characteristics of Turkish earthquakes," in Proceedings 11th World Conference on Earthquake Engineering, Acapulco, Mexico, 1996, no. 1270.

[6] T. L. Youd, I. M. Idriss, R. D. Andrus, et al., "Liquefaction resistance of soils: summary report from the 1996 NCEER and 1998 NCEER/NSF workshops on evaluation of liquefaction resistance of soils," Journal of geotechnical and geoenvironmental engineering (ASCE), vol. 127, no. 10, pp. 817-833, 2001.

[7] K. O. Cetin, R. B. Seed, A. Der Kiureghian, et al., "Standard penetration test-based probabilistic and deterministic assessment of seismic soil liquefaction potential," Journal of Geotechnical and Geoenvironmental Engineering, vol. 130, no. 12, pp. 1314-1340, 2004.

[8] S. S. Liao and R. V. Whitman, "Overburden correction factors for SPT in sand," Journal of Geotechnical Engineering, vol. 112, no. 3, pp. 373-377, 1986.

[9] R. B. Seed, K. O. Cetin, R. E. Moss, A. M. Kammerer, et al., "Recent advances in soil liquefaction engineering: a unified and consistent framework," in Proceedings of the 26th Annual ASCE Los Angeles Geotechnical Spring Seminar, Long Beach, CA, 2003.

[10] K. Hazirbaba and E.M. Rathje, "A comparison between in situ and laboratory measurements of pore water pressure generation," in Proceedings of the 13th World Conference on Earthquake Engineering, Vancouver, Canada, 2004.

[11] B. R. Khatibi, M. H. Sutubadi, and G. Moradi, "Liquefaction potential variations influenced by building constructions," Earth Science Research, vol. 1, no. 2, pp. 23, 2012. 